\title{
The study of religion and theology at the University of Pretoria - A century of endeavour in conditionalistic perspective
}

\begin{tabular}{|c|c|}
\hline $\begin{array}{l}\text { Author: } \\
\text { J.S. Krüger }{ }^{1}\end{array}$ & \\
\hline $\begin{array}{l}\text { Affiliation: } \\
{ }^{1} \text { Department } \\
\text { and Christian } \\
\text { of Theology, } \\
\text { Pretoria, Sout }\end{array}$ & $\begin{array}{l}\text { of Dogmatics } \\
\text { Ethics, Faculty } \\
\text { niversity of } \\
\text { Africa }\end{array}$ \\
\hline $\begin{array}{l}\text { Project leade } \\
\text { Project numb }\end{array}$ & $\begin{array}{l}\text { : J. Buitendag } \\
\text { er: } 02402343\end{array}$ \\
\hline $\begin{array}{l}\text { Description: } \\
\text { Prof. Dr Kobus } \\
\text { participating ir } \\
\text { project, 'Unive } \\
\text { and Theology', } \\
\text { Prof. Dr Johan } \\
\text { Departement } \\
\text { and Christian } \\
\text { Faculty of The } \\
\text { of Pretoria, So }\end{array}$ & $\begin{array}{l}\text { Kruger is } \\
\text { the research } \\
\text { rsity, Education } \\
\text { directed by } \\
\text { Buitendag, } \\
\text { f Dogmatics } \\
\text { thics, and Dean, } \\
\text { logy, University } \\
\text { th Africa. }\end{array}$ \\
\hline $\begin{array}{l}\text { Correspondin } \\
\text { J.S. Krüger, } \\
\text { krugejs@unis }\end{array}$ & $\begin{array}{l}\text { g author: } \\
\text { ac.za }\end{array}$ \\
\hline $\begin{array}{l}\text { Dates: } \\
\text { Received: } 24 \text { J } \\
\text { Accepted: } 30 \\
\text { Published: } 21\end{array}$ & $\begin{array}{l}\text { une } 2016 \\
\text { uly } 2016 \\
\text { Nov. } 2016\end{array}$ \\
\hline $\begin{array}{l}\text { How to cite th } \\
\text { Krüger, J.S., } 2 C \\
\text { of religion anc } \\
\text { the University } \\
\text { A century of e } \\
\text { conditionalist } \\
\text { HTS Teologies } \\
\text { Theological St } \\
\text { a3575. http:// } \\
\text { org/10.4102/l }\end{array}$ & $\begin{array}{l}\text { is article: } \\
16, \text { 'The study } \\
\text { I theology at } \\
\text { of Pretoria - } \\
\text { ndeavour in } \\
\text { c perspective', } \\
\text { e Studies/ } \\
\text { udies 72(4), } \\
\text { dx.doi. } \\
\text { ts.v72i4.3575 }\end{array}$ \\
\hline $\begin{array}{l}\text { Copyright: } \\
\text { (c) 2016. The } \\
\text { Licensee: AOS } \\
\text { is licensed un } \\
\text { Creative Comr } \\
\text { Attribution Lic }\end{array}$ & $\begin{array}{l}\text { ISthors. } \\
\text { IS. This work } \\
\text { der the } \\
\text { nons } \\
\text { ense. }\end{array}$ \\
\hline Read online: & \\
\hline 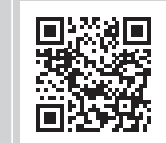 & $\begin{array}{l}\text { Scan this QR } \\
\text { code with your } \\
\text { smart phone or } \\
\text { mobile device } \\
\text { to read online. }\end{array}$ \\
\hline
\end{tabular}

This article suggests a theoretical and methodological perspective primarily hinging on the categories of Horizon, Totality and conditionalism, with an outspoken mystical orientation, radically relativising yet simultaneously treasuring diverse religious expression. This model was developed with a view to interpreting the history of religions, in this case applied to the history of the Faculty of Theology at the University of Pretoria from 1917 to 2017.

Utilising this perspective, the history of the faculty is analysed in terms of three qualitatively distinct yet continuous epochs, overlapping with the three epochs of South African history during the twentieth century: 1902-1948, 1948-1994 and 1994 to present. In particular the article focuses on two dimensions of theological existence at the University of Pretoria: firstly, its interaction with the state over this century, that is, its political existence during the decades prefiguring apartheid, during apartheid and during the aftermath of apartheid; secondly, its relationship with the wider world of religious pluralism over the past century, implying its notion of religious truth. Differences of emphasis and conflicts during the century, involving both sets of problems, are explained and understood conditionalistically and with reference to Totality and Horizon. Racial exclusion and religious exclusion are understood as mutually determining and are both informed by and dependent on a certain view of religious truth.

In the context of its own ambit this article has a reconciliatory intention, not evaluating the mistakes of the past in terms of the categories of sin and guilt, but rather in terms of tragic misjudgements of situations: shortcomings in historical hindsight, sufficiently wide peripheral vision, realistic foresight and sufficient insight into the epochal conditions of the times and the essence of religion. Greed and hatred, seemingly ingrained in human nature, are taken to feed on such lack of insight.

\section{Introduction}

The academic study of Christian theology in particular and religion in general at state universities in South Africa presently finds itself in a precarious situation. This problem can be attributed to a number of factors, including the gradual erosion since the end of the Christian Middle Ages of theological authority and ecclesiastical power in the epoch of modernity, largely but not exclusively triggered by the massive impact of modern science on society and its implications for traditional religion. In the South African context, the rise and fall of apartheid, a system and ideology in some circles (in the context of this article, Reformed circles) based on Christian principles, was a tremendous shock not only to socio-ethical thinking in those circles, but to the very foundations of belief, including the authority of the Bible and the Christian belief system as such: to some the theos of theology had lost its plausibility. In addition, in the new type of society, emerging religious pluralism was an undeniable fact, and faculties of Christian theology came to be seen in some quarters as sites of one-sided religious propaganda and therefore of potential conflict.

For at least these reasons it increasingly seemed to some (including some policymakers) that the study of theology at state universities was out of place in the present academic and wider cultural milieu; it was seen as undermining the foundations of a secular society in the global context. Clearly, if theology is to be continued as a field of study at South African state universities, particularly as a faculty in its own right, a new vision for the future is necessary. That implies an understanding of the past, to which this article is intended to contribute. Future and past are mutually implicated (see point 7 below), as the Old Testament prophets remind us. Understanding the past rests on meticulous uncovering of previously unknown raw data pertaining to what happened, but it also requires imaginative acts of seeking and finding or creating meaning; this article contributes to the second task more than to the first. 
At a time of upheaval comparable to our present one, Nicholas of Cusa (Cusanus, 1401-1464) in his monumental little book De pace fidei (1453) sought a 'peace of faith'. This work was produced as a response to the fall of Constantinople to the Turks in that same year, marking the end of the Roman Empire. Cusanus addressed only the inter-religious dimension of the developments at the beginning of the modern epoch, not the sociopolitical dimension: only a peace among religions, not a peace between religion and state. Paying my respects to him but widening the scope of our imagined pax, I focus here on two dimensions of theological existence at this institution of higher training: (1) its sociopolitical involvement and (2) its relationship to other religions. In both contexts the word 'apartheid' is useful. Historically speaking, the first dimension was the more dramatic of the two but also easier to dismantle over time; the second dimension, reconfiguring the relationship of various religions and imagining an accommodating space beyond them, the more difficult and foundational. By 1994/2000 the first was virtually over and done with and the second hardly begun.

For reasons of space, other vitally important aspects of the theological agenda in the more distant and the recent past do not receive attention in this article, for example the liturgical expressions of faith and the relationship between theology and the sciences (the pax with science). The latter dimension includes both the natural sciences such as physics and biology as well as human sciences such as philosophy, psychology and sociology. Moreover, this article is less about personalities and more about structural developments; less about the actors, more about the play - indeed, a serious play, a tragedy rather than a comedy -in three acts.

\section{Conditionalistic theoretical and methodological perspective}

Interpreting what happened over the last century presupposes a certain theoretical and methodological perspective. In this examination of the first century of the Faculty of Theology my perspective is not a theological one in the literal or traditional sense of the word, for example, finding the guiding hand of God in its history, or judging its history in accordance with a supernaturally revealed Word or will of God. What is termed 'metaphysical mysticism' here does not coincide with any of the academic disciplines of Theology (or any of its subdisciplines), Philosophy, or Science of Religion/ Religious Studies/Religion Studies, yet it is a 'discipline' in its own right, extending each of these three while respecting the integrity of each, and intended as an inclusive space where they may meet and converge. The perspective put forward here, and its present application, includes the following (Krüger 2003:25-71; Krüger s.a.).

1. A historical-critical component. This term is here not restricted to the reading of canonical texts, but used as applicable to the explanation of every religious teaching, institutional arrangement, system of morality, relationship with wider society and so on, as situated in a specific set of unique circumstances and embedded in a specific epoch (chunk of time, exhibiting certain characteristic features) largely determining (causing) the qualities of such items. This principle is a safeguard against anachronistic (mis-)understandings.

2. The approach involves a phenomenological understanding of the intentionality structure of the religious actors obliged to speak, act and organise in their various contexts with the toolsets available to them. What exactly did he, she or they mean subjectively, and why (for what reasons)? Again, anachronistic moralism ignoring the ditches sometimes separating epochs, now from then, would in this perspective be counted as superficial.

3. The approach followed here affirms the relative identity and continuity of a specific religion or religious subgroup continuing through time, yet does not settle the question of any specific normative identity (e.g. what is 'true' Christianity?). That question is not part of my present brief, yet I would favour a combination of three aspects: the foundational early texts, the growing and developing body of cumulative thought over changing times, and certain features common to all or at least most of the various branches of, for example, Christianity.

4. The approach affirms from the very outset the homoversal solidarity of all of humankind and all its religions; it disapproves of any attempt to isolate any religion from that inclusive social and historical context, attempting to absolutise any one in particular. The fact of cross-religious connections is not an afterthought, but point of departure of the study of any one religion. It is the map on which I locate (i.e. interpret) the past century of the Theological Faculty at the University of Pretoria.

5. The perspective extends points 1 to 4 above to involve what I would call the interpretation of the tendentional drift of all religions in the same direction, towards an absolute, uncrossable, indeed unreachable, Horizon. This does not amount to a tendentious superimposition of one's personal whims on the religious material, but proceeds from taking the truth claims of all religions seriously. Then go as far as can be gone and all religious words, conceptual systems, symbols and myths and institutional arrangements peter out where silence is the only adequate response. That is the way of 'metaphysical mysticism'.

6. Horizon is not only the end of religion, but also the origin of religion. Horizon implies the appreciation of, profound respect for, religion in all the richness of its historical manifestations in all cultures and epochs. Horizon ends and cancels and also embraces; nihilates and treasures; relativises and provides a loving, conserving perspective; radically transcends and creates space for seeing a coherent Totality, integrating as much as possible of what is empirically accessible in the world; sees a wide world of precious religious meaning beyond any specific system (say, Christian theology), yet treasures Christian theology as a magnificent historical resource of great significance. This article distances itself from the dominant materialistic, consumerist culture of today, threatening even the sphere of academe. Christian theology and the worldviews encapsulated in all religions are in their 
togetherness a treasury of the human species, to be protected and unlocked for the good of society - and universities should take responsibility for that.

7. Totality on this side of Horizon is not imagined as a static, closed system. On the contrary, what appears inside Horizon does so as multiform sets of mutually conditioning factors; as processes marked by change, all beginning and all ending, not as timeless, eternal essences. In this perspective our time of upheaval and uncertainty (also affecting Christian theology) is not viewed or judged from an Augustinian perspective postulating some perduring, eternal civitas Dei, sub specie aeternitatis; but, before ultimate Horizon, sub specie vacuitatis, in which the true identity of any religious system (as that of every other thing on Earth) is constituted by mutuality, reciprocity, inter-relatedness, service ending in silence and eventual emptiness - not by self-entitlement, power, domination or violence, verbal or otherwise, however subtly done. Relationality replaces self-sufficiency as a marker of identity. I situate the faculty in the widest conditionalistic context. This would include the following.

- It would include the mutual interaction of individuals and the wider group(s) of which they were part.

- It would also be interested in how past, present and future were mutually implicit. By that I do not simply mean continuous flow, but the fact that an anticipated future structures the past (i.e. people's understanding of the past), determining action in the present, impacting on the future and so on.

- It would focus on the structural issue of the mutually conditioning relationship of theology and wider religious, economic, cultural, social and political aspects of life in the broadest sense of the word - and indeed, over the past century the Faculty of Theology overlapped with various larger social collectivities in complex reciprocal relationships.

- It favours neither forced exclusion nor homogenising forced inclusion, but cooperative pluralisation, which has certain moral implications (justice).

- Thus, it would see this institution as embedded in humanity in its totality and in all its religious and other expressions, also part of the process of past, present and future of all life on Earth.

In short, a conditionalistic perspective would be interested in the simultaneous interaction of a great number of pushing and pulling factors. In this it places other accents than a traditional theological approach would. It also differs from a Marxist perspective (to use an older example), reducing religion to being determined by material (economic) conditions and playing an ideological, supportive role. Moreover, it differs from Max Weber's more fruitful perspective (another older example), which allows for a stronger mutual interaction of the factors of religion and society, but largely limiting the latter to the economic element.

8. In this interpretation no religion is awarded special or exclusive supernatural origin. The following notions ensue:
- respect and gratitude for the history and reality of one's own singular religion (but formal allegiance to any one is not laid down here as sine qua non)

- respect for every other singular religion

- respect for the totality of all religions in the largest context of a real but essentially conditionalistic Totality of all things

- respectful silence before emptying Horizon.

These notions need to be held in mutual balance. All religion is humanly constituted, so many attempts are made to say the unsayable, intuiting the ever-evasive Horizon. Concepts of divinity and sociocultural circumstances are mutually conditioned. All pictures of God are of a kind, conditionalistically produced, which by no means excludes regarding some expressions as superior to others: more serviceable to the wider context, a better approximation of awe-filled silence. Awareness of its own relativity is superior to claiming absoluteness for itself. Collective self-grooming, assuming an aureole of eternity, which can readily happen in the case of religious institutions as fundamentalism in various religions demonstrates, has been a constant in religious history, but from the perspective of this article it is not exactly the highest achievement.

9. At any given time, any religion or religious subgroup seeks a core of order, yet at the same time inevitably has a less than perfectly integrated fringe of freedom. It is always somewhere in a process of spiralling inwards or drifting outwards, seeking conformity within, yet deeply in need of receptively and creatively opening up to what lies outside itself. Time and circumstance place heavy constraints on people's scope and freedom to think and act. And what dense sets of powerful forces had to be negotiated by religious intellectuals and academics (i.e. theologians) in South Africa from 1917 to 2017.

10. The dynamics of religious change do not necessarily occur as smooth evolutionary transitions from one stage to another but more often than not in the form of forced adaptation to unforeseen crises - perhaps as a result of external challenges threatening the survival or integrity of the religious group, perhaps by a breakdown of the inner logic and consistency of the religious group. Such dramatic changes are more often than not accompanied by immense inner-group tension and conflict. The notion of conditionality invites the notion of tragedy: people must act, try to do the right things according to their lights, but they are often, perhaps mostly, incapable of anticipating unintended consequences that would have led to different courses of action, if anticipated. Greed and hatred, seemingly ingrained in human nature anyway, are taken to feed on such chronic lack of insight into the precipitating antecedents, the accompanying factors and the probable outcomes of action.

11. In the dynamics of change of religious groups one finds the visionaries, the lonely voices ahead of their time calling from the wilderness, and perhaps heard - or more often not; the self-conscious small avant-garde determining the direction of new developments; the larger body of 
progressives, front-liners following the creative head, setting the tone and inaugurating a new future; the large body of conservatives, not clambering onto bandwagons but cautiously hanging back and playing their role in tasting the new before allowing the group to swallow it; and the resisters, sometimes angry, sometimes disconsolate, hoping against all odds to undo what cannot be undone any more, once a certain stage has been reached. They need not be reactionaries in the negative sense associated with that word, usually a blunt instrument in a rhetoric of contempt. They could be champions of a lost cause with heroic qualities of their own; Proclus, magnificent last representative of the dying Classical epoch, comes to mind. The methodology advocated and followed here would not adoringly or deprecatingly draw up simplistic schemes of saints and villains, champions of orthodoxy and heretics, and would not contribute to any personality cult of those who may have had more social and political impact or public acclaim than others. It would not think simplistically in terms of icons and demons but be inspired by a desire to understand all the actors involved in the extremely complex struggles of the past, their agonies and their joys, and would throughout maintain an attitude of fair equanimity, realising the outcome when Horizon, silencing all, was approached. In that last context, that future Totality on Horizon, even the conflicts of the past are pacified - they too have their place in the large scheme of things.

In sum: as I see it, the highest tests for an academic faculty dealing with ultimacy would be the extent and quality of its insight into and its self-orientation in the large inclusive homoversal past; its peripheral vision of the larger world, including nature surrounding it, and its relationship with all religions; and its anticipation of and solidarity with a universal future. By 'future' I do not mean mere temporal futurity, but a way forward for humanity as a whole in nature as a whole, in an overall Horizon where all arrogant claims to absolute truth peter out. That Horizon is the ultimate context of any faculty dealing with humanity's visions of ultimate truth and value, of which Christian theology may, indeed could and should, be a vital component and to which it may make an inestimable contribution.

\section{Epochs}

Building on a prehistory of some three decades (see Loader 1989; Oberholzer 2010: chapter 2; Van der Merwe 2008), the internal structural development of the faculty (the oldest theological faculty in South Africa) unfolded over three epochs with distinctive characteristics:

1. It started officially in 1917 with the founding of the Faculty of Theology, open to students of all churches. Apart from the Nederduitsch Hervormde Kerk van Afrika Netherdutch Reformed Church of Africa (NRCA), the Presbyterian Church of South Africa was de jure involved from the beginning until 1933; however, de facto not a single Presbyterian student was trained for ministry during 1917-1933.
2. In 1938 a second leg (Section B) of the faculty, representing the Nederduitse Gereformeerde Kerk Dutch Reformed Church (DRC) was launched, in addition to what would from that date be the (NRCA) Section A of the faculty (Oberholzer 2010:chapter 3). In effect this arrangement virtually amounted to two Reformed faculties, sharing an identical doctrinal basis, serving the same linguistic and cultural group and both partly financed by the state (university, tax payer) and partly by the two denominations involved.

3. In 2000, in tandem with the new post-1994 dispensation, the two theological sections merged, and in addition the faculty became a multi-ecclesial Christian theological faculty, seeking to emphasise common ground among various Christian denominations (yet Reformed at that stage) without alienating students from their respective churches and faith bases. In 2002 the Uniting Presbyterian Church in Southern Africa officially became a faculty partner, followed by the Evangelical Presbyterian Church in South Africa in 2004 and the Uniting Reformed Church in Southern Africa in 2012. Names such as V. Vellem, E. Mahlangu, M. Makubele, M. Speckman, T. Kgatla, T. Maluleke, J. Pillay, S. Dube and Z. Dube, who would in coming years by followed by others, enriched the innerfaculty multilogue as well as its contribution to wider Christianity and society. The faculty had entered an era of inclusive, ecumenical theology that would steadily widen in coming years.

As far as the wider political dimension of the twentieth century is concerned, the stream of events could likewise be divided into three epochs:

1. 1902 (the end of the Anglo-Boer War) to 1948 (the establishment of systematic apartheid by the Nationalist government): 46 years.

2. 1948-1994 (the reign of apartheid: 46 years).

3. 1994 to present (recent history since the final fall of apartheid, the reign of the ANC government): 23 years thus far.

I overlapped the inner-faculty epoch with political epoch 1. Both were marked by still fairly open-ended, oscillating beginnings.

Theological epoch 2 overlapped with political epoch 2. Both sections of the faculty were caught up in the wider political events in the country and embroiled in a titanic struggle to define themselves in the dynamics of the wider situation. During this period the two sections did not escape tensions between themselves, related to the quite distinct histories of the two constituting churches: the NCRA with its strong roots in the communities developing in the North as a result of the Great Trek in the mid-nineteenth century and the DRC with its (at least initially in the faculty) fairly strong Cape connections. For most practical purposes, the two sections operated as two parallel faculties. Both sections mostly collaborated with the government of the day; however, at certain times, in certain individuals, the faculty certainly 
anticipated and helped to inaugurate new thinking. In the 1970s, political, economic and demographic developments and international pressure started to strangle apartheid, and the faculty was not spared the ordeal of taking sides. Dramatic changes in outlook and structure were inevitable.

Theological epoch 3 overlapped with political epoch 3 . African nationalism finally took power. During this time a concern with social justice and wider concerns of relevance to Southern Africa as a whole started to develop in the faculty.

Across these limited theological and political epochs but with roots going back to the more distant past of the meeting of the West and Africa in South Africa, a set of interlinked challenges formed the backdrop of theology at the University of Pretoria as at other institutions of theological study. These challenges, swelling over time as inevitably and irresistibly as the rising of the tide at full moon and only facilely branded as always somebody's fault, could for present purposes be grouped into at least the following six.

1. Secularisation: Here understood as the gradual, increasing loss of relevance of traditional Christianity in wider society, secularisation has manifested as the loss of institutional power in the political sphere; the loss of intellectual authority and influence in the general cultural sphere, mainly as a result of the scientific revolution in the modern age and the concomitant process of technological development; and the erosion of traditionally held Christian views regarding a variety of issues. These issues include the origin and development of the universe, the origin and development of life, the origin and development of humankind and its position in cosmos, the position of women, and gay and lesbian rights. This set of challenges had already in principle taken off a century or two before the era of colonisation, during the apex of the European Middle Ages.

2. Africanisation in the context of colonisation: The indigenisation of Christianity in Southern Africa has challenged both Westerners and Africans to the limits of what their respective cultures can tolerate and been implicated in enormous social, economic and educational discrepancies in opportunity and position between the newly arrived and those who have been here for at least several centuries, in one instance (the San) for tens of thousands of years. The crash of apartheid marked the end of the era of colonisation and the beginning of a still unclear future. It cut right into the heart of the theological enterprise, confronting the faculty with unprecedented challenges and, let it be added, a singular opportunity for a creative fresh start.

3. The battle for the safeguard of cultural identity in the North on the side of the Voortrekkers / Afrikaners vis-à-vis British Imperialism: The reaction to this battle reverberated throughout the twentieth century.

4. Religious pluralisation: The serious encounter of South African-European Christianity with non-Christian religions with equally long and impressive intellectual histories, as part of a process of increasing religious globalisation, has challenged all involved. Judaism and Islam have been conversation partners of Christianity since the Middle Ages, but religions from farther east, particularly Hinduism, Buddhism and Taoism, has just begun to enter the peripheral vision of South AfricanEuropean Christianity, with a subtle force still not appreciated at the present time.

5. A seeming aporia has accompanied Christianity since its beginning, which confronts all religions: reconciling religious formalisation (in for example institution, teaching, ritual and art) with mysticism transcending all of that - for 'the wind bloweth where it listeth' (John 3:8). All collective religious identity formation, however impressive and seemingly everlasting, is deeply unsettled by the end and origin of all religion on Horizon. In this connection I wish to distinguish (but not as mutually exclusively or adversely - in fact they are continuous) the concepts of spirituality and mysticism. I see spirituality as specific to a certain religious tradition (e.g. Christian, Jewish or African spirituality) and mysticism as eventually transcending that towards an empty, contentless Horizon.

6. Through and in all of this the central question remained to develop a message and set an example deriving from a profound insight into the ultimate conditions of existence and a corresponding morality of universal love and justice, as Jesus lived and taught in terms of his belief in the Heavenly Father.

In their lattice-like mutual interdependence these problems contributed to the field of forces that theology had to study.

\section{The interaction of state and institutionalised theology}

This section will content itself with general trends and only slight mention of a few individual names.

\section{From the launch of the faculty (1917) to the launch of the apartheid system (1948)}

From the start the conjuncture of challenges 1 to 6 above formed the context of the debates and strategies surrounding the nature of theological education at university level in Pretoria; from the start the inextricable nexus of general culture and theology, of politics and religion, was clearly in evidence.

By 1917 the civil religion of Afrikaner Christian Nationalism, which started to emerge in Pretoria in neo-Calvinist circles at the end of the nineteenth century (du Toit 1983) had been expressed in the programme of principles of the Nationalist Party (formulated in 1914). The Great Trek and the AngloBoer War were still fresh in the memories of its followers, and Afrikaner poverty and the struggle for identity of the time fed this civil-religious orientation. Its main worldview adversary in white society at the time was liberalism, with its emphasis on the primacy of the individual, but this idealistic civil-religious vision remained largely ineffectual in the 
North. Thirdly, between those two moved white integrationism, expressed in the programme of the South African Party, founded in 1910, and enshrined in the Union Buildings (completed in 1913). It excluded blacks from its civil-religious orientation and political programme. In 1917, under the auspices of empire and commonwealth, it basked optimistically and comfortably in the sunny new Union of South Africa. Fourthly, there was African nationalism, having found political expression in the African Nationalist Congress (formed in 1912) with its own civil-religious programme, a blend of African religion and Christianity.

At the time of the establishment of the Transvaal University College (since 1930 the University of Pretoria) and its Faculty of Theology in 1917, white liberalism and black African nationalism were very distant from the levers of power, and Afrikaner Christian Nationalism and white integrationism contended for political control. By the end of the 1930s the door on alliances with blacks was closed in both of these dominant streams as they moved closer together. Up till the launching of apartheid in 1948 both churches constituting the faculty were more or less evenly associated with both these civil-religious trends, white integrationism becoming weaker after that momentous date.

Theologically, the initially largely de facto NRCA faculty struck out on a dialectical third course between the ultraorthodox Reformed and modernist-liberal extreme positions held in nineteenth century Holland. In its religiopolitical thinking, this essentially Voortrekker Church never adopted the neo-Calvinist position of the Dutch theologian Abraham Kuyper with its fundamentalist streak, but its position was not liberal either. As far as politics and particularly race were concerned, it moved in the broad middle stream cut by the only relatively different Afrikaner nationalist and white integrationist models of thinking. Article III of its church order, dating back to the Boer Republic (the ZuidAfrikaansche Republiek) restricted membership to whites only (it would be rescinded in 1997). Yet during the first two decades of the faculty's existence, white reformed political thinking, although not tolerating racial mixing in any sense (socially, sexually, religiously), lacked the hyper-charged atmosphere of Afrikaner resentment that would build up gradually in the 1930s to become a near-unstoppable force in the 1940s until the outbreak of the Second World War. In 1940 C.H. Rautenbach, influential predikant and later elder of the NRCA and brilliant lecturer in Philosophy at the University of Pretoria (UP) from 1939 until 1948, articulated the position of a powerful bloc of opinion that would in time dominate NRCA theological thinking: 'our own blood ideology' is an essential part of 'the Christian-religious national character of the Afrikaner, rooted in Calvinism' (Rautenbach 1975:74-87).

The addition of the Nederduitse Gereformeerde (DRC) Section B to the faculty in 1938 did not change a view, held widely and at least implicitly in both the white integrationist and Afrikaner Christian nationalist varieties, of the nonnegotiability of racial segregation. New Testament scholar E.P. Groenewald, one of the first DRC appointees and of equally impeccable personal and intellectual integrity as Rautenbach, offers evidence parallel to that of Rautenbach. The DRC Section at the University of Pretoria was launched shortly after the dismissal of J. du Plessis from the University of Stellenbosch in 1932. Du Plessis was a white integrationist figure, both theologically and politically mildly liberal: Christianity was the summary and completion of all other religions, and the only saving one; and in race matters he was a benevolent paternalist, rejecting enforced segregation. The outspoken assumption of the DRC was that the new theological facility in the North would not rock the unstable DRC boat by sailing close to Du Plessis, and Groenewald, ranking the well-being of the DRC above all else, certainly did not in either theology or politics. Cautiously orthodox along biblical-realist lines, he shared the Afrikaner fear, growing and already widespread at the time, of being swamped numerically by 'non-whites' and religiously by a wide range of fatal '-isms'. In 1947, on the eve of the 1948 victory of the Nationalist Party, he compromised his theological standing but not his biblical-realistic stance by legitimising apartheid from the Bible (Cronje 1947:40-67).

Overall, the attitude of the state (including leverage at the level of internal university management) from 1917 to the dramatic break of 1948 was rather tentative. The faculty was allowed to go about its business according to its theological principles and public conscience. And from its side the faculty (both sections) as such was not formally and publicly committed to any ideological or civil-religious stance in particular. By and large both the constituent churches, the professors teaching at the faculty and the market serviced by it provided a combination of, an oscillation between, Afrikaner Christian nationalism and white integrationism, varying in strength in various individuals and situations and not coming down overwhelmingly on either side. Yet the days of being 'liberal', either theologically or politically, were numbered, and that would be the case for half a century.

\section{From the launch of the apartheid system (1948) to its fall (1994)}

At least since 1948 the coexistence of the state on the one hand - to be more precise, two successive governments (of the Nationalist Party and the ANC), with contradictory programmes of social engineering - and on the other hand an institution carrying a message of the ephemerality of all earthly kingdoms and, rooted in that, an ethos of universal love, proved to be a daunting challenge. Political epoch 2 left no doubt: it was a state actively promoting an ideology and programme of Christian nationalism and racial separation, and presented as implying the active Christianisation of society. The latter point is not without significance. At public school level, the apartheid state did not tolerate the benevolent knowledge and understanding, let alone promotion, of non-Christian religions. Christian National Education programmatically promoted Christianity, and Christianity alone. Only Christian theology was allowed the right to promote itself at UP, as elsewhere in the country at tertiary state institutions. 
The relatively different approaches of doing theology in the two churches remained. Both were generally middleorthodox but in different ways: the NRCA overall combining the ethical tradition in late nineteenth and early twentieth century theology of the Nederlandsch Hervormde Church in Holland, critical theology and a mild form of confessional theology (Beukes 2008; Dreyer 2014; Loader 1989). At the time of writing the attempt to find a balance among the various modalities in the NRCA was still in full swing and in fact had gained new momentum (Van Aarde 2012). The DRC in contrast broadly continued the orthodox-pietistic tradition exemplified in an Andrew Murray in the wake of the seventeenth-century Second Reformation (Nadere Reformatie). In the DRC section of the faculty as such original Calvinism, which then became neo-Calvinism (Kuyper), and then local Afrikaner Calvinism, so influential in the wider DRC in the 1960s and 1970s, did not find a strong foothold.

The NRCA by and large continued the model of volkskerk, maintaining an intimate relationship between church and people (ethnic group) and was at the time of writing this article struggling to rid itself of that. During most of this period the DRC rather ambivalently followed de facto volkskerk thinking and was at the time of writing endeavouring to establish social relevance along widely accepted lines of ecumenical Christian and missionary thinking.

Of importance is the manner in which the Reformed theology of Karl Barth was received in the faculty, expressing a convergence of thinking in Systematic Theology in both sections as well as a similarity in the justification apartheid. Barth had been an unwavering critic of Nazism. However, during the middle decades of the century the two dogmaticians A.B. du Preez of the DRC and B.J. Engelbrecht of the NRCA remarkably interpreted the theology of Karl Barth to support the rightist political programme of apartheid. On the one hand this probably indicates that apartheid was not a simple extension of Nazism. It was, in fact, rooted in the much wider nineteenth century German romanticism. On the other hand, that particular interpretation of Barth was without doubt slanted for apologetic, ideological motives, not transmogrified in a calculated manner, but probably unintended and unnoticed by the two figures, both so heavily involved in and supportive of the racial policies of the time. However, starting in the 1960s a trickle of criticism against apartheid in both constituent churches slowly became a fairly steady stream, pioneered by B.J. Marais in the DRC section and A.S. Geyser in the NRCA section since the 1950s.

The late 1960s in the DRC Section B saw a new generation of scholars replacing the founding fathers. They brought with them not only new academic-theological impulses but also a greater critical distance from the Afrikaner church-andpolitics connection. Yet even there it was well-nigh impossible to break cleanly out of the DRC-Afrikaner establishment, and even there the favouring of two virtually identical churches in one state institution was not challenged; religious truth was still taken to be particularly or for all practical purposes exclusively invested in Reformed Christianity. In 1980 three professors (C.F.A. Borchardt, A.B. du Toit and J.A. Heyns) were among the eight (the other five were from Stellenbosch) to witness against racial apartheid, in an openly stated continuation of the Protestant Reformation. During the 1980s Heyns was a particularly prominent critic of apartheid, cautiously dismantling that structure, yet sailing remarkably close to the political power of the mid-1980s and doing so on a mid-orthodox Reformed theological platform. Yet that did not prevent a split in the DRC in 1987 with the formation of the Afrikaanse Protestantse Kerk.

In the NRCA section Geyser suffered the worst fate to befall any faculty theologian over the last century. He was found guilty of Christological heresy in 1962 in a trial in which political and theological interests inextricably merged (Oberholzer 2010:chapter 6; Van Aarde, De Villiers \& Buitendag 2014). Christology and racial segregation could not be unscrambled, but the high-handed treatment of Geyser did not hide the fact that significant cracks in the edifice of apartheid had started to appear. I find it noteworthy that Geyser also had a marked spiritual interest, attested to by his translation of Thomas à Kempis's classical work De imitatione Christi (fifteenth century) into Afrikaans in 1952. Radical religion (mysticism) indeed often underlies radical politics. However, Geyser was not a religious radical or visionary, rather a moderately orthodox, pious believer and Biblecentred theologian; I read him as perhaps not intentionally but in essence, tendentionally, on the way to Totality and Horizon.

The extremely narrow straits in which theologians found themselves are obvious and critics of apartheid such as Marais, Geyser and Heyns were not theological innovators in a radical sense in terms of point 11 above, but rather progressives realising an already clearly emerging future. The above figures prepared the soil for the new. However, the cautious conservatives who nevertheless did not turn their backs on the future also deserve benevolent understanding. And then there were the extreme traditionalists, refusing or incapable of leaving a bygone epoch so clearly riddled with injustice, acting out an almost predestined role in social movements, in the process earning their share of conciliatory understanding.

Here a distinction needs to be made between epoch-specific, epoch-bound ways of thinking and, in contrast, thinking continuing diachronically across and transcending the fashions of times, relating to values embracing the totality of humanity throughout the duration of its presence on Earth. Discrimination based on factors such as gender, class, race, educational development, culture or language are not merely epoch-specific peculiarities, but timeless affronts to the dignity of all people (victims as well as perpetrators) in terms of epoch-transcending human values, however self-evident such actions may appear to be to actors, trapped in webs of factors. In terms of the model employed here, discrimination is seldom the expression of sheer malice, but rather a fitting 
together of a group's fixation on itself (its heavily emphasised collective substantiality and identity, with the usual human needs and greed associated with that); interacting with its aversion towards 'others', equally substantialised and fixed as inimical, threatening, competing entities; locked into a narrow vision incapable of taking into account an array of interacting circumstantial factors. The entrenchment in 'us' in contradistinction from 'them' or 'you' is part of this seemingly ingrained tendency to reduce complex flow and overlap and reciprocity to fixation and isolation. In this perspective racial (and religious) touchiness is not understood as simply spontaneously combusted, fuelling on sheer untriggered hatred, but as always conditionalistically reactive: reacting to sets of circumstances not comprehended (grasped in their totality) and perceived as threats in terms of what is understood to be isolated, enduring, substantial entities. Indeed, the lack of insight into Totality and Horizon (see points 5, 6,7 and 8 above), which is essentially a religious, mystical category, meshes with our present topic, namely politics. Again, racial aversion in whatever guise fed on religious aversion, understood in a wide sense.

In what sense were at least some members of the faculty, consisting of committed Christians of high personal integrity, at least morally guilty of the apartheid debacle? To what extent did the faculty as an entity in its own right commit mistakes? The interpretation of the past in this article prefers to remove sin and guilt from the whip hands of accusers as well as flagellants somehow finding satisfaction in constant self-flogging, and to replace that attitude with the humanly kinder yet religiously more radical perspective of observing a tragic, myopic misunderstanding of complex situations spanning quite different epochs (e.g. between the times of the Old and New Testaments and twentieth-century South Africa). It could not accommodate various races in an encompassing, pax-creating understanding. Such outlooks missed the opportunity of embracing and being embraced by larger totalities of humankind and nature - and by the allemptying and all-allowing Horizon.

\section{The final fall of apartheid (1994) and the recent past since}

As was the case during political epoch 1, the overall initial attitude of the ANC state in the recent past (epoch 3) towards religion could be described as friendly-neutral. Yet a certain trend could be discerned. Starting as generally religionfriendly, as its policy on religious education in public schools (promulgated in 2003) demonstrated, the ANC state gradually drifted into a more neutral stance, carrying overtones of a less enthusiastic attitude. These shifts clearly had implications for state institutions, including universities and their faculties of theology. After all, did theological faculties not provide ideological props for apartheid? The fact that such faculties were also bulwarks against the flatland of materialistic hedonism and secularism was sometimes ignored or not registered. The developing dominant sentiment regarding theology at state institutions of higher learning seemed to blend with a measure of increasing neutralism, shading into indifference, and containing elements of antireligious sentiment inspired by ideological commitments, materialistic scientism and modern consumerism, the quantification and commercialisation of research being symptoms of these.

The discomfort of the state and state-sponsored university governing bodies reflected the tone of wider public debates in the media. Militant atheism squared off against ultraconservatism. The worst scenario for both theological faculties and university managements would be to fall between these two chairs; the best would be the production of a truly future-creating pax as alternative to both. A constructive centre would not be easy to establish - indeed, would need to be established, with care and understanding. Centres of growth do not simply appear miraculously all by themselves.

From Section B, P.J.G. Meiring was seconded to the Truth and Reconciliation Commission in 1996, thereby contributing to the process of pax-making in the offing in South Africa after the year of destiny, 1994. This was also a signal that Section B had taken leave of the ideology of racial separation. Yet the virtually inescapable conditionalistic mesh of theology and wider political context, whether of the secular or ecclesiastical variety, was very much in evidence early in the twentieth century. In 2005 the faculty (now unified but in this case addressing DRC students' complaints levelled against DRC lecturers) found it necessary to react apologetically in essentially traditional-orthodox style (du Toit 2013:69-70), not readily reconcilable with critical theology.

As far as the NRCA constituent of the faculty was concerned, such doctrinal issues were no longer in evidence. Its heresy ordeal lay four decades in the past. And the conditionalistic entanglement of politics and Christian theology that had been present in the past and had become a deadly snare in the decades of the pre-1994 context would be loosened: in 2009 five NCRA theologians (J. Buitendag, Y. Dreyer, J.A. Loader, A.G. van Aarde and E. van Eck - only Loader not being a member of the faculty) issued a public statement that apartheid could not stand the test of theological and biblical scrutiny. The ideal of volkskerk was abandoned, the book closed and the scene set for an entirely new chapter. Yet that did not prevent a split in the NRCA in 2012-2014, as happened in the DCR in 1987. Among the factors precipitating this breakaway, theological themes, mixed with political sentiments, were still very much in evidence, as had been the case throughout the century.

Did the faculty taken as a whole always have the macrohistorical hindsight, sufficiently wide peripheral vision, realistic foresight, sufficient insight into the epochal social conditions of the time and the essence of religion to respond adequately to the six massive challenges mentioned earlier? Generally in the past it turned out to be supportive of the powers and dominant trends of the times, not because of cynicism, but because it saw no other options. Collective theological thinking and mainline political thinking were largely mutually supportive. Overall, those challenges were 
not met. It would be facile to simply find the reasons for the shortcomings only in the blind or recalcitrant disobedience to timeless scripture and eternal God in the persons involved. The problems had deeper roots: an entire Afrikaans epochal manner of thought was in the process of coming to an end, entering a new stage. In such straits the idea of compromise would have crossed many a mind many a time, probably without realising it or using the word, and the distinction between right and wrong, wise and foolish in all their shades could only have appeared clear at the cost of naivety or pseudo-innocence. Yet, over the last decades the civilreligious deadlock and the defensive attitude that had held sway in previous decades appeared to have been broken.

\section{Theology, the study of non-Christian religions and mysticism}

It is today commonly accepted that apartheid was politically and morally out of touch with the times and a deeper morality. However, the more intractable problem was not Christian social ethics as the good or bad application of a solid base of truth but such basic 'God-speech' itself. This problem manifested in the relationship between Christian faith and other religions and in the quality of truth attached to Christian theology.

During the founding years of the faculty white integrationism ruled the roost, its main intellectual driving force, J.C. Smuts, was an influential cabinet minister and had an input in its formation and development. He had a universalist tendency, believing in a Divine Source of Being. In principle this style of thinking could have favoured a widely inclusive model for the study of religion at the newly founded faculty, but that did not quite transpire. Yet, highly commendable from my present interest, the curriculum of Theology as such at the inception of the faculty built on a B.A. degree with Hebrew, Greek, Latin and Philosophy, thereby providing future theological students with a broad basis in the history and philosophy of religion of the Middle East and West. At the fourth-year level the curriculum of Theology included History and Psychology of Religion, and at the fifth-year level Philosophy of Theism and Religion (taught by Prof. E. MacMillan of the Presbyterian Church until his retirement in 1933), flanked by Christian apologetics (Oberholzer 2010:chapter 2; Van der Merwe 2008:37). From the perspective of this article that augured well for the future.

Indeed, the fluctuating fortunes of the study of non-Christian religions in the faculty present a useful instrument for interpreting its more distant and recent past. During its first epoch the stage seemed to be set for a clear inclusion of Science of Religion (to use that somewhat older term for the moment) as part of a broad academic programme.

During its second epoch, in the second half of the twentieth century the NRCA (Section A) continued that broad approach, adding Missiology to that interest, but secondarily. The NRCA always incorporated a substantial religiophilosophical component, mainly of a Kantian and phenomenological variety, into its theological programme, relating theology to a wider rationality. This was represented in the work of, for example, faculty members F.J. van Zyl and P.J. van der Merwe (Beukes 2008). Moreover, in other theological disciplines the broad set of 'ethical'-existential orientations in the NRCA (connecting with a moderately liberal theological orientation in late nineteenth century Holland) made a positive relationship between Christian theology and the study of other religions thinkable. For example, in the Old and New Testament the possibility in the NRCA tradition of doing Christian theology on a religionswissenschaftlich basis was acknowledged, thereby doing justice to the historical nature of Christianity as a religion among religions. This route did not always gain overwhelming support in wider NRCA church circles, because of the intricate conditionalistic relations of the time, as explained earlier in the article. Yet this type of thinking, also present in other members of both sections of the faculty, must be acknowledged as a significant resource for a future reorientation of the faculty, announcing itself in the recent past.

In the DRC (Section B) a different approach developed. As far as the wider orientation in the world of religion was deemed necessary, the study of non-Christian religions would here take shape as an ancilla theologiae, subservient to the missionary calling of the church: dialogue with non-Christian religions was part of the Missiological agenda (Meiring \& Niemandt 2013:127). The study of non-Christian religions would take place in Science of Religion, well taught but nevertheless understood as a junior partner to Missiology and capped by a Christian theologia religionum - not by theorising arising from the history and phenomenon of religion as a generic field as such. In the perspective of this article the study of other religions as part of Christian apologetics and mission work as such was perfectly in order, but restricting the study of non-Christian religions to that was a limitation that could not be continued in the new epochal situation after 1994/2000 (epoch 3).

Relevant to our present interest, the discipline of Biblical Studies became the programme Biblical and Religious Studies in 1985: the pluralistic angle was added, and at least a window on a wider panorama was opened. In the twentieth century a refiguring of the faculty to include other religions on an equal footing would probably have exceeded the limits of the possible, both in thinking and in the politics of the situation. In the recent past that has clearly emerged as necessary in order for the faculty to be relevant and survive. After the introduction of multireligious Religion Education in South African schools in 2003 the unified faculty introduced the discipline of Science of Religion and Missiology. This was a step forward but essentially also continued the as-yet unresolved ambivalence of earlier decades: it would be done from a Christian theological perspective (Meiring \& Niemandt 2013:129-132).

All of the above were interlinked with racial thinking: black, coloured and Indian members of the Reformed churches themselves (not to mention non-Christians) remained absent 
from the faculty, the receivers of a benevolent missionary impulse, but not participating partners. Only in 1989 would the first black student (Dr Hara from Malawi) receive a doctorate in Theology. Racial apartheid and religious apartheid were both erected on the attitudinal pillars of distancing, privileging and domination. As it turned out, it would be easier for theologians to abandon racial apartheid than religious apartheid.

The thrust of this evaluation of the past is not the ideal or norm of subsuming other religions under Christian theology, but the institutional accommodation of such religions at a state university, creating the space for a true encounter of religions as equals in a pluralistic society. It must be added that at the level of systematic (dogmatic) theology, neither Barth nor Brunner, arguably the most influential figures in both sections in this regard for most of the century, encouraged that (for Brunner, see e.g. his 1960:103 f).

Over the past century several avenues of dealing with the challenges raised by the undeniable fact of global religious pluralism were available to the faculty in various modes. Syncretism, the mixing and matching of odd items from various religious quarters and not necessarily integrated, was certainly an 'irreal' theoretical possibility, but in practice and for good reasons this never materialised in the faculty. So the most significant to consider were the following, not necessarily mutually exclusive in all cases.

\section{The absoluteness of Christianity}

Firstly, the route of conservatism over ultraconservatism at times bordering on fundamentalism, amounting to a denial of any truth value in non-Christian religions, was trod by some throughout the century without any second thoughts and not without implicit and sometimes explicit triumphalism. This view of the 'absoluteness' of Christianity was largely the default option during most of twentieth century thinking in Reformed circles. In its heyday Afrikaner Christian nationalism and Reformed theology worked on the assumption that it aspired to, and largely succeeded in, grounding its theological and civil-religious expressions in the eternal Word of eternal God. The margin left for understandable uncertainty, legitimate ambiguity and wise relativity was narrow: people are weak and unsighted by sin, but God and his Word are perfect, the confessions of faith more than adequate and Christianity absolute.

\section{Third person pluralism}

Overlapping with the absoluteness of Christianity, there was third person pluralism ('they'). Here non-Christian religions were studied, even with some interest. That was a move beyond mere indifference, but such religions were still held at arm's length and often studied for purposes of converting non-believers to Christianity. This did not exclude occasional friendly mutual visits, so to speak, but the boundaries were clear. This was institutionalised in a variety of Religious Studies strongly ensconced in Reformed Theology and supporting Christian mission work, mentioned above.

\section{Second person pluralism}

In the beginning of the twenty-first century, overlapping with third-person pluralism, second person pluralism began slowly developing ('you', with an incipient possibility of 'we'). In subjects mainly designed for the purposes of training prospective teachers at primary and secondary schools and offered in other faculties but largely taught by theologians, tentative steps towards such macro-ecumenism were taken. Administratively combined with Theology, this in principle created a promising common space of true inter-religious discourse. Here the study of non-Christian religions would obviously be of a quite different variety than in third-person pluralism.

\section{Negative theology}

The close of the epoch of apartheid marked a singular moment of truth in the history of the faculty, as of South African Reformed religion in general. The seemingly divine and irrefutable certainties concerning the truth held during that era, undermined over some 20 years, tottered. One way out of the impasse, sought and found by some, was to find refuge in negative theology, a soft variety of mysticism: God is beyond words and concepts, but he remains the ground of all being. Of singular significance and a clear sign of a new time altogether, undoing what had been done in the case of Geyser 40 years before, was the portrait of Jesus as 'fatherless in Galilee' by A.G. van Aarde (Van Aarde 2001): precisely in his frailty on the fringes of society, Jesus reveals God. This was in fact the resuscitation of the classical NRCA ethical style of thinking. Over the decades the existentialist-ethical type of thinking in the NRCA section and the mysticism coupled with Reformed orthodoxy in the DRC Section were latent seeds that might have developed into a more radical metaphysical mysticism (see sections 'Totalism' and 'Absolutism' below). Yet the faculty as a whole was (to adopt the still-useful model of Ernst Troeltsch), as it had been throughout, the strong theological arms of the church type of religious association; it was decidedly not a contra-establishment sect, and not marginal mystical friendship either. Neither was it a space for an open-ended study of religion as such and religions in the plural.

\section{Totalism}

By 'totalism' I mean the kind of thinking that could have attempted to encompass all religions, together with other cultural expressions such as art and science, in a comprehensive vision. In such a totality the constituent parts, including various religions, would be respected in their unique individuality. However, the wider sociocultural circumstances of the twentieth century surrounding the faculty and university and largely determining its manoeuvring space simply did not allow for such a possibility to become reality. Adopting such a position would have meant certain dismissal from the faculty for the lecturer attempting that. 


\section{Absolutism}

There is, however, a further step that hypothetically might have but in reality probably could not have been taken. The last imaginable move for theology could have been absolutism, by which I mean the realisation of the petering out of all cultural constructs (including theological and religious ones yes, they too are constructs) on a last Horizon. By 'absolutism' (from the Latin $a b$-solvere: to loosen, unbind, dissolve) here is not intended the same as 'absoluteness' above; indeed, the opposite is meant. Yet, this radically mystical line of thought would not only have ultimately nihilated (that is not the same as negative destruction) religion and theology but would also have embraced them in their penultimacy as the noblest expressions of the human spirit. This approach, I submit, may have exceeded the explicit intention of the biblical authors but would have followed the implicit tendention at least latently present in all great religious documents. There is a deeper dimension than formal adherence to the intentional message of the biblical authors. As far as I can tell, this route was not explored in the faculty. Realistically the study of this metareligious space could not have taken place in a Faculty of Theology as such, but in a department, somehow linked to Christian theology in a larger Faculty of Religion and Theology. It was only in the recent past, under the crushing impact of the fall of a regime, of a mode of knowing and being, that this possibility tentatively started to come to light. Indeed, a parallel can be postulated with the crisis of European Christianity exactly a century ago with the First World War. Yet a return to Barthian theology with its reductionist focus on Christ would not be the way to go - rather an exploration of open space. Pre-1994 and pre-2000 the page to a truly open religious narrative was not - simply could not - be turned: to a vision appreciatively aware of not only the contributions made by various Christian denominations, but also of the entire history of the human religious search, in the large, embracing Horizon of awed silence from which mystery speaks.

\section{Looking back}

What makes the centenary of the Faculty of Theology at the University of Pretoria so poignant is that it coincides with a break between two times: it occurs at the dusk or dawn between two different yet connected days. An epoch has come to its end, and the time for something new has arrived. Indeed, in the recent past promising steps not to withdraw into a mere backward-looking stance but to work towards a reconstruction of the faculty aligned to meet contemporary and anticipated future challenges were taken during the deanship of Prof. J. Buitendag. The observer of events in the recent past is struck by the pathos, the sense of urgency, comparable to the mood during the two decades preceding 1917 (Oberholzer 2010: chapter 1), of creating a facility meeting the needs of the time.

In line with its conditionalistic perspective this article partly operated in a modus irrealis: not as far as the present and future are concerned, but the past (it is after all a remembrance); conscious not only to what did happen, but also to what did not happen, to what might, could, would, should have happened, if .... To what extent could things have been different, could people have acted differently? Why did things happen as they did; why did people act the way they did? Looking back on a century in this perspective precludes ending up in simplistic blaming or excusing or defending, wholesale dumping or naïvely attempting to salvage what cannot be continued. It would understand things in the context of prevailing causes and conditions, time-bound situations, thereby avoiding anachronistic judgements. To use a critical example: however much one may strive to understand the system of apartheid from 1948 to 1994 contextually, that system could have been recognised by Reformed theologians of the time (in fact was by some) as inherently racist, and out of touch with the social, demographic and other developing components of the time; such a judgement from the vantage point of this article would in my view not be anachronistic, but realistic. Yet the challenge remains to understand why, historical-critically and intentionally so many of them did legitimise that system theologically. Understanding the limits of what was possible at a given time but did not happen is not a waste of time, but useful in order to understand what did in fact happen, and why. Ultimately, to understand is to absorb into benevolent equanimity, allowing to pass into larger totalities and eventually to dissolve on Horizon.

The risk is on the one hand to content oneself with a romantic, uncritical glorification of the past, longing for, somehow, a perpetuation of that past and covering up the cracks while praising the Lord. Looking back to the more distant as well as the recent past, the faculty has much to be proud of. It consistently provided theological training and produced research on a par with the best international standards, delivered by highly trained professional theologians, some of whom had made significant contributions to their fields. The faculty provided creative leadership to church and wider society and produced several moderators from all four church partners of the faculty. After 2000 the constituent churches and the faculty as a whole took leading roles in contributing to the general welfare of the wider South African society. Space and the methodological strategy of this article did not allow paying tribute to such individuals and programmes. In any event, a mere continuation of the old ways could not be maintained indefinitely. In a new set of circumstances new strategies to serve the theological cause had to be devised, which is what increasingly happened in the faculty since the watershed of 1994, particularly over the last few years.

An opposite and equally unsatisfactory way of dealing with the past would be to blandly reject it for political and ideological or religious reasons. In the latter case, 'sin' and 'guilt' may come to mind as appropriate theological terms. Of course humanity is beset with greed and hatred, but also good people make serious mistakes. Are we, actors of today, necessarily faring better? How can we tell - whoever 'we' may be? By all means, admit and regret mistakes made in the past, whether from greed and hatred or from misguided bona fides, and learn from them, then set things straight as far as possible and 
find reconciliation. However, the malodorous smell of the mire of guilt, never really washed off completely, is psychologically unhealthy and inhibits positive action. In the recent past confession of faith and confession of guilt at times tended to blend in a theological style reminiscent of Barth and Barmen.

Yet see that in context too. Over the last century theology, whether pro- or anti-apartheid, mostly sought and found a speech befitting a strong God, appropriate to what was perceived to be harsh times. It found heavy and often heavyhanded application not only in state affairs but also in, for example, its treatment of women and gays. In the recent (post-1994) past things mellowed, but still a three-tier hierarchical ontology (God, human, the rest of nature) was adhered to in most theological circles: still an ontological apartheid of God and creation, and still Christ is defined in terms of supreme and sovereign lordship. A political and social-institutional epoch had ended, but not necessarily a theological one, with an uncanny family likeness to apartheid thinking. It was still a time of heavy conflict, and still the outdated high ground of authoritarian irrefutability was sought on more than one and opposite sides of the political spectrum. From the point of view of this article, none of this is rejected outright as false but strongly relativised as conditionalistically constructed, more or less suitable to the wider situation, and in any event ultimately silenced. Triumphalist theology might, could, should (in the modus irrealis) have come to the end of the road left, right and centre, but it did not necessarily.

Probably the six challenges mentioned earlier proved to be a bar too high in the pre-2000 faculty as a whole. Those actors, particularly during the time of high apartheid, had their involuntary blind spots, partly due to often unconscious or unintended connections to ideological and worldview assumptions. The people who acted in the prevailing conditions and thus constituted the faculty over 10 decades were not superhuman. Yet undoubtedly the vast majority acted with great personal sincerity and integrity, responsible (respond-able) to the best of their insight and ability in difficult times. A true historical sense means to be able to weave positive aspects of the past into the tapestry of a vision for the future and to come to terms with the problematic ones. In this connection the existential style of doing theology in the NRCA remains a promising resource, as the mystical tradition in the DRC tradition. These elements (present over decades in the pre-2000 Reformed faculty) could, when coupled with the new and very relevant concern with the social well-being of sub-Saharan Africa and Africa as a whole (emerging in the faculty over the last two decades), make a significant contribution to a new ecumenical Christian and wider inter-religious institutional dispensation and to society in general, intellectually as well as socially. Clearly contemporary society is in need of something more than economic-technological legitimacy or brute power.

Acknowledge mistakes made in the past candidly and, having drunk the bitter cup, move on, striving for the creation of a meaningful present and future. It is probably impossible to win all of the conditionalistic tugs of war inevitably engaged in simultaneously. So should one exonerate past generations for not reading the wider context better? Not at all, but one's privilege is to be compassionate and realistic in one's judgement and not define the past in terms of simplistic formulae on any side. The greatest and hardly avoidable temptation during the past century was the closure of various in-groups over against competing indifferent or hostile out-groups, each with its own internal and external politics: various denominations, church(-es) and state (the latter with all its own struggles for power), races, Christianity and other religions; feeling vulnerable and under attack or somehow superior; and all involved in shifting alliances. Such is human social life, and religious groups are not necessarily different from other groups. Yet they should and could be different, motivated by their own origins and resources, ultimately pointing towards a pax fidei, a vision of Totality and Horizon. In promising principle the faculty has always been open to that and in the recent past took promising steps in that direction. And as in the past, 'responsibility' can still be defined as the optimal reconciliation of the ideal and the attainable. May the best for this invaluable religio-academic institution lie ahead.

\section{Acknowledgements}

I wish to thank the following persons for making valuable information available during private conversations: Jaco Beyers, Graham Duncan, Hennie Pieterse, Andries van Aarde and Johan van der Merwe. Due to space the sources consulted, whether in written or spoken word, are not referred to in detail.

\section{Competing interests}

The author declares that he has no financial or personal relationships that may have inappropriately influenced him in writing this article.

\section{References}

Beukes, C. J. \& van Aarde, A.G., 2000, 'C.H. Rautenbach, P. S. Dreyer en C. K. Oberholzer: Hulle nalatenskap en die pad vorentoe', HTS Teologiese Studies 56(1), 1-37. http://dx.doi.org/10.4102/hts.v56i1.1695

Beukes, J. 2008, 'Voices carry: An archaeology of the Hervormd approach', HTS Theological Studies 64(1), 73-109. http://dx.doi.org/10.4102/hts.v64i1.4

Brunner, E., 1960, Die Christliche Lehre von Gott. Dogmatik, I. Zwingli Verlag, Zürich.

Cronje, G., 1947, 'Werklikheid en ideaal', in G. Cronje, W. Nichol \& E.P. Groenewald (eds.), Regverdige rasse-apartheid, pp. 40-67, Christenstudenteverenigingmaatskappy van Suid-Afrika, Stellenbosch.

Dreyer, P.S. (ed.), 1975, Prof. Dr. C. H. Rautenbach. Versamelde Geskrifte, HAUM, Pretoria.

Dreyer, T.F.J., 1998, 'Spiritualiteit, identiteit en die etos van die Nederduitsch Hervormde Kerk', HTS Teologiese Studies 54(1\&2), 289-314. http://dx.doi. org/10.4102/hts.v70i1.2054

Dreyer, W.A., 2014, 'Wanneer een twee word: 'n Perspektief op resente gebeure in die Nederduitsch Hervormde Kerk van Afrika', HTS Teologiese Studies/Theological Studies 70(1). http://dx.doi.org/10.4102/hts.v70i1.2054

Duncan, G.A., 2003, '350 years reformed in South Africa: The contribution of the Reformed Presbyterian Church in Southern Africa', HTS Theological Studies 59(1), pp 47-64. http://dx.doi.org/10.4102/hts.v59i1.649

Du Toit, A., 1983, 'No chosen people: The myth of the Calvinistic origins of Afrikaner nationalism and racial ideology', American Historical Review 88, 920-952. http://dx.doi.org/10.2307/1874025

Du Toit, P.R., 2013, 'Rol van die Ned Geref Kerk in die geskiedenis van die Fakulteit Teologie (UP)', in D.J. Human \& J. van der Merwe (reds.), Die Ned Geref Kerk en Teologiese Opleiding, pp. 32-90, Universiteit van Pretoria, Pretoria.

Krüger, J.S., 2003, Sweeping whirlwinds: A study of religious change. Reformed religion and civil religion in the city of Pretoria (-Tshwane) (1855-2000), UNISA Press, Pretoria. 
Krüger, J.S. s.a., Horizon. History of and perspectives in metaphysical mysticism (in final stage of publication)

Loader, J.A., 1989, 'Ontstaan en eerste periode van die Hervormde teologiese opleiding aan die Universiteit van Pretoria', HTS Teologiese Studies 45(2), 413-416. http://dx.doi.org/10.4102/hts.v45i2.2284

Loader, J.A., 1996, 'n Hervormde tradisie as heelmiddel', HTS Teologiese Studies 52(4), 566-589. http://dx.doi.org/10.4102/hts.v52i4.1543

Meiring, P.G.J. \& Niemandt, C.J.P., 2013, 'Godsdiens- en Sendingwetenskap', in D.J. Human \& J. van der Merwe (reds.), Die Ned Geref Kerk en Teologiese Opleiding pp. 119-144, Universiteit van Pretoria, Pretoria.

Nicol, W. (red.), 1946, Die ontstaan en groei van ons teologiese fakulteit en huldebetoon aan die grondlegger Prof GM Pellissier, Voortrekkerpers Bpk., Pretoria.

Oberholzer, J.P., 1992, 'Terugblikke op die Fakulteit Teologie (Afd A)', HTS Teologiese Studies 48, 575-584. http://dx.doi.org/10.4102/hts.v48i3/4.2421

Oberholzer, J.P., 2010, 'Honderd Jaar Kerk en Teologiese Opleiding: 'n Kroniek van die Hervormde Kerk', HTS Teologiese Studies/Theological Studies, 66(3 suppl. 9). http://dx.doi.org/10.4102/hts.v66i3.916 (available in separate chapters, indicated in article by reference to chapter number).

Pont, A.D., 1994, 'Historiese perspektiewe op die kerklik-teologiese opleiding van die Nederduitsch Hervormde Kerk aan die Universiteit van Pretoria', HTS Teologiese Studies 50, 95-110. http://dx.doi.org/10.4102/hts.v50i1/2.2545

Rautenbach, C.H., 1975, 'Ons lewensopvatting', in P.S. Dreyer (red.), Prof. Dr. C $H$ Rautenbach Versamelde Geskrifte, pp. 74-87, HAUM, Pretoria.

Van Aarde, A., in press, Jan Christiaan Smuts, the University of Pretoria and the Faculty of Theology, Coffee Table Book, Faculty of Theology Centenary, University of Pretoria.
Van Aarde, A.G., 1992, 'A.S. Geyser, teologiese dosent 1946-1961', HTS Teologiese Studies 48(1\&2), 159-182.

Van Aarde, A.G., 2001, Fatherless in Galilee: Jesus as child of God, Trinity Press International, Harrisburg, PA.

Van Aarde, A.G., 2012, ' $n$ Postliberale perspektief op ' $n$ ekklesiologiese modaliteit as ' $\mathrm{n}$ ecclesiola in ecclesia - heroriëntasie in die Nederduitsch Hervormde Kerk van Afrika', HTS Teologiese Studies/Theological Studies 69(1), Art. \#2012, 1-14. http://dx.doi.org/10.4102/hts. v69i1

Van Aarde, A.G., De Villiers, P.G.R. \& Buitendag, J., 2014, 'The forgotten struggle of Albert Geyser against racism and apartheid', HTS Teologiese Studies/Theological Studies 70(1). Art\#2820, 1-10. http:/dx.doi.org/10.4102/hts.v70i1.2820

Van der Merwe, J.M., 2013, 'Die reis van die Ned Geref Kerk oor 75 jaar: 1938-2013', in D.J. Human \& J. van der Merwe (reds.), Die Ned Geref Kerk en Teologiese Opleiding, pp. 4-31, Universiteit van Pretoria, Pretoria.

Van der Merwe, P.J., 2008, 'The contribution of the Netherdutch Reformed Church of Africa (NHKA) to theological training at the Transvaal University College HTS Theological Studies 64(1), 27-48. http://dx.doi.org/10.4102/hts.v64i1.32

Van der Watt, P.B. (red.), 1988, Deo Gloria! Teologiese Fakulteit 1938-1988, NGKB, Pretoria.

Van Wyk, D.J.C., 1998, 'Wortels en agtergronde van Hervormde teologie en kerkwees in Suid-Afrika', HTS Teologiese Studies 54(1\&2), 245-263. http://dx.doi.org/10. 4102/hts.v54i1/2.1405

Wethmar, C.J \& Veldsman, D.P. 2013, 'Dogmatiek en Christelike etiek (1938-1999-2013)', in D.J. Human \& J. van der Merwe (reds.), Die Ned Geref Kerk en Teologiese Opleiding, pp. 91-118, Universiteit van Pretoria, Pretoria. 